Journal of Agrometeorology 23 (2) : 221-227 (June 2021)

\title{
Assessment and monitoring of drought in Chitradurga district of Karnataka using different drought indices
}

\author{
S. SRIDHARA*, G.M. CHAITHRA and PRADEEP GOPAKKALI \\ Center for Climate Resilient Agriculture \\ University of Agricultural and Horticultural Sciences, Shivamogga, Karnataka, India \\ "Corresponding author: sridharas1968@gmail.com
}

\begin{abstract}
Drought is a natural disaster due to less precipitation than the normal that can occur irrespective of climate regimes. Impact assessment of drought and monitoring are the most important mitigation stratregies to combat the drought effects. As the single index cannot assess all the drought conditions, in the present study multi-variate indices approach has been used to assess and monitor drought. Five indices were assessed using precipitation data such as deciles index (DI), percent normal (PN), China-Z index (CZI), Z-Score index (ZSI) and standardized precipitation index (SPI). Monthly total precipitation data was used to calculate drought events occurred during the period 1967-2017 in different talukas of Chitradurga district of Karnataka, India. The assessment revealed that SPI, CZI and ZSI performance was similar in identifying drought. PN was very much responsive for the rainfall events that occurred during the particular year however, it exhibited variations in dry conditions. DI was not that much satisfactory in identifying drought conditions. Among the five indices assessed, SPI seems to be the best indicator to predict the drought onset than the other four drought indices. Therefore SPI can be recommended for assessing and monitoring the drought in Chitradurga district of Karnataka, India.
\end{abstract}

Keywords: Drought, standardized precipitation index (SPI), deciles index (DI), percent normal (PN), China-Z index (CZI) and Z-Score index (ZSI)

Deficit of rainfall for prolonged period affecting human life, water resources and economy of the country to an huge extent is referred as meteorological drought. Assessing and monitoring are the key determinants in mitigating drought risk on a global scale in arid as well as in semi-arid regions to ensure natural resources and agricultural management. In recent past, various types of drought indices are developed for assessing the drought intensity. Dogan et al. (2012) opined that drought characteristics in quantitative form given by drought indices will be useful to mitigate drought for the policy makers. Various indices for characterizing drought were developed by several researchers like, Palmer formulated two drought indices i.e., the Palmer Drought Severity Index (PDSI) and Crop Moisture Index (CMI) during 1965 and 1968 respectively, Gibbs and Maher (1967) developed the Deciles Index (DI), Shafer and Dezman (1982) developed the Surface Water Supply Index (SWSI), Bhalme and Mooley (1980) developed the Bhalme and Mooley Drought Index. Further, in 1993, McKee et al. (1993) formulated Standardized Precipitation Index (SPI), Byun and Wilhite (1999) proposed Effective Drought Index (EDI) and Soil Moisture Deficit Index (SMDI) by Narasimhan and
Srinivasan (2005). Recently Reconnaissance Drought Index (RDI) was developed by Tsakiris et al. (2007). Majority of the above said indicators consider precipitation, soil moisture, temperature, ground water, stream flow, potential evapotranspiration etc., for calculating drought intensity (WMO, 1975).

Complexity of drought phenomena restricts the use of drought indices only for a particular region as they cannot perform well under varied climatic situations. Some of the examples are PDSI is limited to United states, self calibrating PDSI (sc_PDSI) for arid and semi-arid regions (Dai, 2011), the CZI and MCZI (modified China-Z index) are extensively used in China (Wu et al., 2001). As SPI performs well under varied climatic conditions and at different time scales, it can be widely adapted to assess drought intensity on a global scale including India. Many researchers like Barua et al. (2011); Deepa et al. (2019); Dogan et al. (2012); Keyantash and Dracup (2002); Morid et al. (2006) and Pradhan et al. (2011) used various criteria like amenablity, clarity and capacity of drought indices to analyse and characterize drought for a specific region. Spatial and Time Series Information modelling (SPATSIM) software was developed by Smakhtin 
and Hughes (2007) which uses five different drought indices simultaneously for estimating drought severity. Comparison of seven different drought indices such as DI, SPI, PN, ZSI, MCZI, CZI and EDI was made by Morid et al. (2006) for monitoring the drought which revealed that DI performance depends on rainfall events whereas EDI on drought intensity. Similar kind of comparsion among six different drought indices (SPI, CZI, MCZI, de Martonne aridity index, PN and ZSI) was made under six varied climatic regions in Iran by Shahabfar and Eitzinger (2013) and they could conclude from the study that out of six indices, CZI, MCZI and ZSI performed well in predicting meteorological drought. CZI, ZSI and SPI were evaluated using monthly total precipitation data for varied time scales where months were in multiples of three (1, 3, 6, 9 and 12 months) at four locations in China by $\mathrm{Wu}$ et al. (2001). The results revealed that, all the three indices used were found effective in predicting, describing and monitoring the drought.

In India, meagre attempts have been made for drought characterization using different indices. First ever attempt was made by Pandey et al. (2008) for studying drought impact in Orissa, India using SPATSIM and they concluded EDI as a better predictor of drought than other indices studied. Jain et al. (2015) also reported that EDI is the best drought indicator for different climate regimes of Central India like temperate, semi-arid, dry and sub-humid regions. Wable et al. (2019) found Standardized Precipitation Evapotranspiration Index (SPEI) as the most preferred drought index for drought monitoring especially in semi-arid river basin of India. Pathak and Dodamani (2019) assessed SPEI, SPI and RDI for the Indian river basin to study the impact of drought and recommended that RDI and SPI are the best drought indicators for humid/subhumid regions whereas SPEI is suitable for semi-arid regions. The study area (Chitradurga) selected is drought prone and been hit by drought 59 times in the past 100 years (Vindhya, 2008). This urges need to assess drought indices to rectify severely affected drought prone areas of Chitradurga district. Based on the findings and research ideas of earlier scientists, the current study of drought assessment has been taken using five different drought indices in Chitradurga district to find out the best drought indicator for monitoring and mitigating the drought.

\section{MATERIAL AND METHODS}

\section{Area and the meteorological data used for the study}

The drought assessment was made for Chitradurga district, Karnataka which is situated at $13^{\circ} 94^{\prime} 38^{\prime \prime}$ North latitude and $76^{\circ} 61^{\prime}$ ' $61^{\prime \prime}$ East longitude, at an elevation of $630 \mathrm{~m}$ above mean sea level. It comes under Agro-Climatic Region-10 and Central Dry Zone (Zone-IV) of Karnataka with mean annual rainfall of $592.5 \mathrm{~mm}$ with 32 rainy days. South-West monsoon (June to September) is the major contributor of rain $(>51 \%)$. Mean monthly minimum and maximum temperatures are $21.0^{\circ} \mathrm{C}$ and $31.8^{\circ} \mathrm{C}$ respectively. April is the hottest month and Decemebr being the coolest. Relative humidity ranges from 58-76 per cent. Six talukas come under this district viz., Challakere, Chitradurga, Hiriyur, Holalkere, Hosadurga and Molkalmuru. Taluka-wise monthly total rainfall data for 51 years (1967-2017) was obtained from the Karnataka State Natural Disaster Monitoring Center (KSNDMC), Bangalore and used in the present analysis.

\section{Drought indices}

In the current assessment study, five different meteorological drought indices like percent normal (PN), the standardized precipitation index (SPI), the deciles index (DI), the CZI and the Z-Score were used for estimating drought severity and duration with a time step of 4 months. All the aforesaid indices work using precipitation data. Detailed description of the drought indices used in this study are presented hereunder

\section{Percent normal (PN)}

Percent normal is the percentage of normal precipitation received during the study period (Willeke et al.,1994). This index can be calculated for different time scales i.e., for season, month and year. However, Hayes (2006) opined that PN is more suitable for characterizing drought for one particular region for only one season. The formula for calculating PN is as follows;

$$
\mathrm{PN}=\frac{\mathrm{P}_{\mathrm{i}}}{\mathrm{P}} \times 100
$$

Where, $\mathrm{P}_{\mathrm{i}} \mathrm{P}_{\mathrm{i}}$ is the monthly precipitation $(\mathrm{mm})$ in time increment ' $\mathrm{i}$ ' and $\mathrm{P}$ is the normal precipitation $(\mathrm{mm})$ recorded during the study period.

\section{Standardized precipitation index (SPI)}

McKee et al. (1993) formulated SPI to estimate the amount of scaricity of precipitation for different time scales which could describe drought impact on various available water resources. SPI uses long-term precipitation data for characterizing drought events and the formula for 
Table 1 : Categorization of SPI, DI and PN values into classes

\begin{tabular}{|c|c|c|c|c|c|}
\hline Values & & Class & SPI range & DI (\%) & PN (\%) \\
\hline 3 & & Extreme & $\geq 2$ & $\geq 90$ & \\
\hline 2 & Wet & Very & $(1.5)-(1.99)$ & $80-90$ & \\
\hline 1 & & Moderate & $(1.0)-(1.49)$ & $70-80$ & $\geq 110$ \\
\hline 0 & & Normal & $(-0.99)-(0.99)$ & $30-70$ & $80-110$ \\
\hline-1 & & Moderate & $(-1.0)-(-1.49)$ & $20-30$ & $55-80$ \\
\hline-2 & Dry & Severe & $(-1.5)-(-1.99)$ & $10-20$ & $40-55$ \\
\hline-3 & & Extreme & $\leq-2$ & $\leq 10$ & $\leq 40$ \\
\hline
\end{tabular}

Table 2 : Relative frequencies (\%) of different wetness categories detected by five indices during $1967-2017$

\begin{tabular}{|c|c|c|c|c|c|c|c|c|c|c|}
\hline & SPI & PN & ZSI & DI & CZI & SPI & PN & ZSI & DI & CZI \\
\hline & \multicolumn{5}{|c|}{ Challakere } & \multicolumn{5}{|c|}{ Holalkere } \\
\hline Normal Years (NY) & 0.2 & 0.5 & 0.4 & 0.0 & 0.2 & 0.2 & 0.5 & 0.4 & 0.0 & 0.2 \\
\hline Near Normal (NN) & 0.7 & 0.2 & 0.3 & 0.1 & 0.7 & 0.7 & 0.3 & 0.3 & 0.1 & 0.7 \\
\hline Moderately Dry (MD) & 0.1 & 0.2 & 0.2 & 0.1 & 0.1 & 0.1 & 0.1 & 0.1 & 0.1 & 0.1 \\
\hline Severely Dry (SD) & 0.0 & 0.1 & 0.1 & 0.1 & 0.1 & 0.0 & 0.1 & 0.2 & 0.1 & 0.1 \\
\hline Extremely Dry (ED) & \multicolumn{5}{|c|}{ Chitradurga } & \multicolumn{5}{|c|}{ Hosadurga } \\
\hline Normal Years (NY) & 0.2 & 0.5 & 0.4 & 0.0 & 0.2 & 0.2 & 0.5 & 0.4 & 0.0 & 0.2 \\
\hline Drought Years (DY) & 0.8 & 0.5 & 0.6 & 1.0 & 0.8 & 0.8 & 0.5 & 0.6 & 1.0 & 0.8 \\
\hline Near Normal (NN) & 0.6 & 0.3 & 0.4 & 0.1 & 0.6 & 0.6 & 0.2 & 0.3 & 0.1 & 0.6 \\
\hline Moderately Dry (MD) & 0.1 & 0.1 & 0.0 & 0.1 & 0.1 & 0.1 & 0.1 & 0.1 & 0.1 & 0.2 \\
\hline Severely Dry (SD) & 0.1 & 0.1 & 0.1 & 0.1 & 0.1 & 0.1 & 0.1 & 0.2 & 0.1 & 0.0 \\
\hline Drought Years (DY) & 0.8 & 0.5 & 0.6 & 1.0 & 0.8 & 0.9 & 0.5 & 0.6 & 1.0 & 0.8 \\
\hline Near Normal (NN) & 0.6 & 0.2 & 0.2 & 0.1 & 0.6 & 0.7 & 0.4 & 0.3 & 0.1 & 0.7 \\
\hline Moderately Dry (MD) & 0.1 & 0.2 & 0.1 & 0.2 & 0.1 & 0.0 & 0.1 & 0.2 & 0.1 & 0.1 \\
\hline Severely Dry (SD) & 0.0 & 0.1 & 0.1 & 0.1 & 0.1 & 0.1 & 0.1 & 0.1 & 0.2 & 0.1 \\
\hline Extremely Dry (ED) & 0.1 & 0.1 & 0.1 & 0.6 & 0.0 & 0.0 & 0.1 & 0.1 & 0.6 & 0.0 \\
\hline
\end{tabular}

calculating SPI is;

$$
S P I=\frac{Y-\bar{Y}}{\sigma} \times 100
$$

Where, $\sigma=$ standard deviation for $i^{\text {th }}$ station; Y $=$ precipitation for $\mathrm{i}^{\text {th }}$ station and $\mathrm{k}^{\text {th }}$ observation and $Y=$ mean precipitation for $i^{\text {th }}$ station. Based on SPI values, the drought is classified into seven groups as: i) If SPI is $(>+2.0)$ Exremely wet ii) (1.5 to 1.99$)$ Very wet iii) (1.0 to 1.49 ) Moderately wet iv) (-0.99 to 0.99$)$ Near Normal v) (-1.0 to -1.49) Modarately Dry vi) (-1.5 to -1.99$)$ Severely Dry and vii) $(<-2.0)$ Extremely Dry.

\section{Deciles index (DI)}

This index works using long-term data of total precipitation received during the month (Gibbs and Maher, 1967). Ranking of this data in descending order (high to low) is done to constitute cumulative frequency distribution which is further divided into ten parts of the distribution or deciles. The first decile represents value of presentation which is $<10$ per cent of all the precipitation values in the recorded data considered for the study. The II $^{\text {nd }}$ decile value lies between $<10$ to 20 per cent and so on. For assessing the drought severity, amount of precipitation received in a month/several months will be compared with the long-term data on amount of precipitation which follows cumulative frequency distribution. Classification of DI: i) Much below normal (Deciles $1 \& 2$ ) - if precipitation $<20 \%$ ii) Below normal (Deciles $3 \& 4$ ) - 20 to 40\% iii) Near normal (Deciles $5 \& 6$ ) - 40 to $60 \%$ iv) Above normal (Deciles $7 \& 8$ ) -60 to $80 \%$ v) Much above normal (Deciles 9 \& 10)- 80 to $100 \%$.

\section{China-Z index (CZI)}

CZI is developed by the NCC (National Climate 

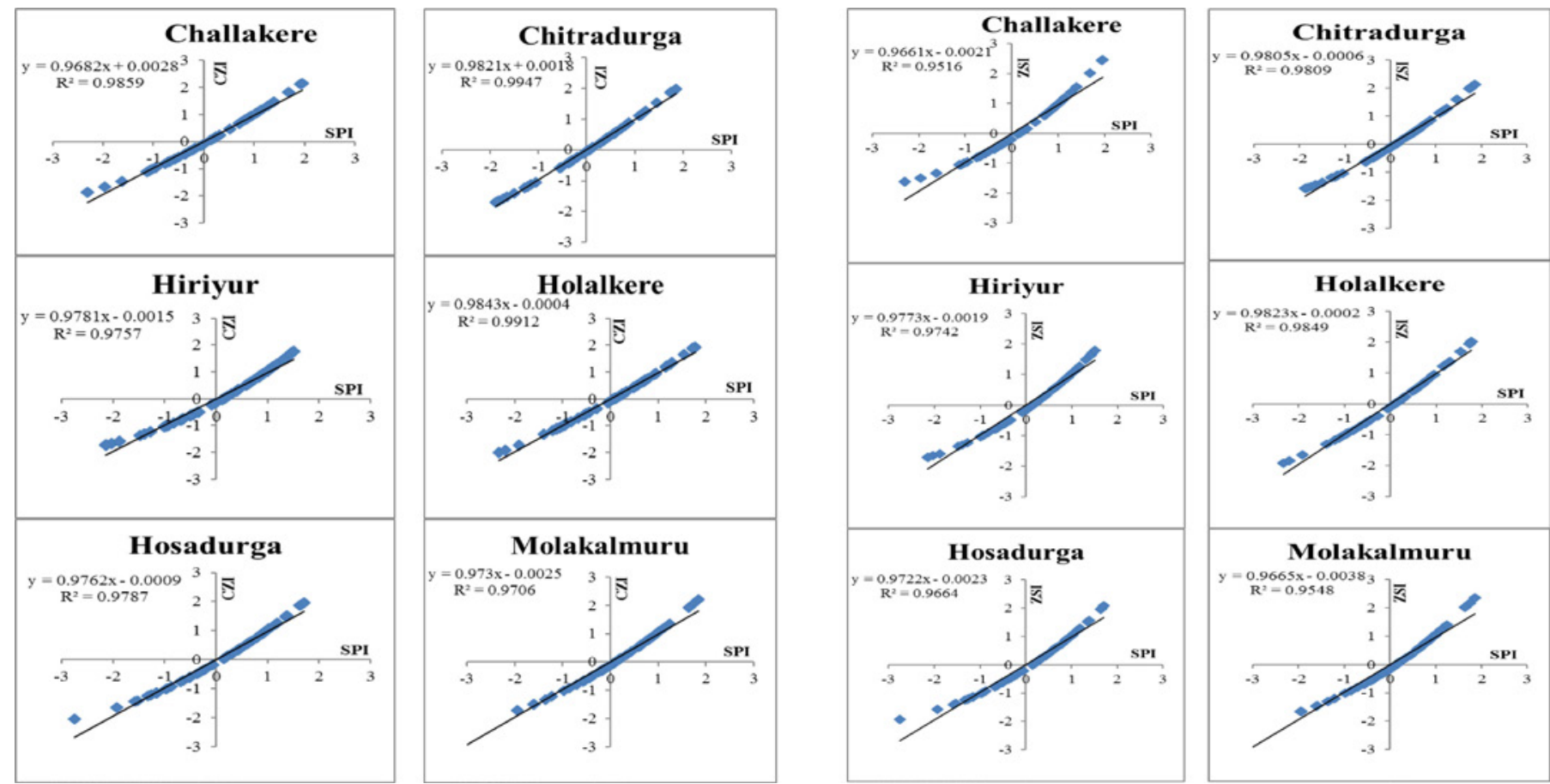

Fig. 1: Scatter diagram for comparsion of SPI with CZI and ZSI for the different talukas of Chitradurga from 1967 to 2017

Centre), China in 1995 as an alternative for SPI when the precipitation means are in Pearson type III distribution (Ju et al., 1997). For calculating CZI following formula has been used;

$$
C Z I_{i j}=\frac{6}{c_{s i}} \times\left(\frac{c_{s i}}{2} \times \varphi_{t j}+1\right)^{1 / 3}-\frac{6}{c_{s i}}+\frac{c_{s i}}{6}
$$

Where ' $i$ ' - time scale of interest and ' $j$ ' refers to the current month; $C Z I$ - CZI's amount in $\mathrm{j}^{\text {th }}$ month for $\mathrm{i}^{\text {th }}$ period; $C_{s}$ coefficient of skewness; and $\varphi_{t_{1}}$ - standardized variation. To reduce the variation in the data set, Modified China Z-Index (MCZI) was proposed by Wu et al. (2001) wherein, mean precipitation was replaced by median precipitation in CZI equation.

\section{Z-Score index (ZSI)}

ZSI is an analogue of CZI. However, in ZSI there is no requirement of gamma or Pearson type III distributed precipitation data as required in CZI. The formula for calculating ZSI is presented below;

$$
Z S I=\frac{P_{i}-\bar{P}}{S D} \times 100
$$

Where $\bar{P}$ - monthly precipitation mean (mm); $P_{i}$ precipitation in a specific month $(\mathrm{mm})$; and $S D$-standard deviation of any time scale. The following classification is used for classification of drought based on ZSI as: Mild
Drought if ZSI is (0 to -0.99), Semi-severe drought if ZSI is (-1 to -1.49$)$, Severe drought if ZSI is (-1.5 to -1.99$)$ and Very Sever Drought if the ZSI is $(<-2)$.

\section{RESULTS AND DISCUSSION}

The relative frequency values depicting wetness categories as assessed by SPI, CZI and ZSI drought indices are almost similar therefore the comparsion among these three drought indices is reliable (Table 2). Whereas, the values obtained by DI and PN indices differed from SPI thus to make them comparable with the classes of SPI, the values of DI and PN were categorized into similar classes as described in Table 1 . Three DI classes of slightly below normal (30-40\%), normal (50-60\%) and slightly above normal $(60-70 \%)$ were combined to form a single class of 'normal' with $30-70 \%$ precipitation which corresponds to the normal class of SPI. For making PN index comparable with SPI, higher values $>110 \%$ were not considered in this study and the values obtained above $110 \%$ were all grouped into 'wet' class (Table 1).

\section{CZI and ZSI Comparison with SPI drought index}

The comparison between CZI and SPI as well as ZSI with SPI was computed by using the values of $\mathrm{R}^{2}$ (Pearson's correlation coefficient) obtained for six talukas considered for the present study i.e., Challakere, Chitradurga, Hiriyur, Holalkere, Hosadurga and Molkalmuru. Comparsion of CZI 

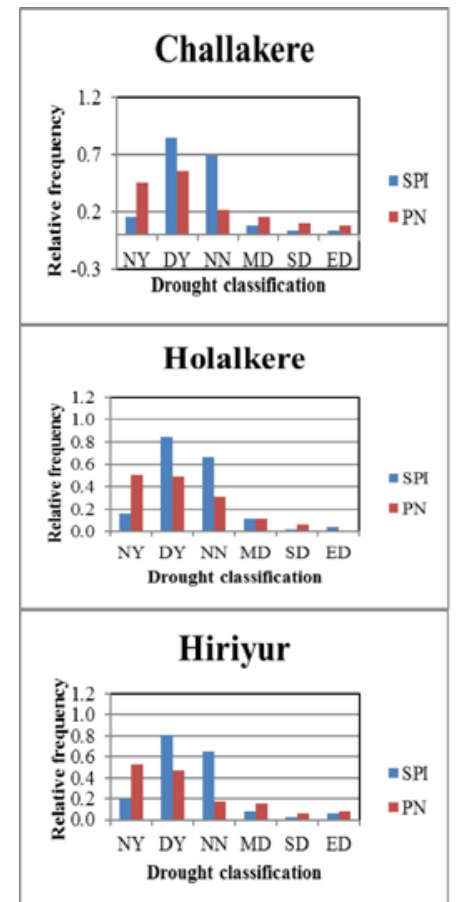
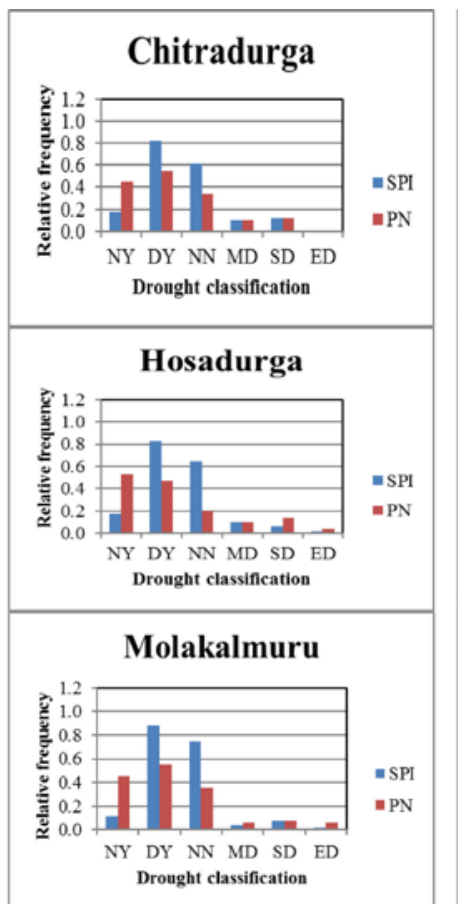
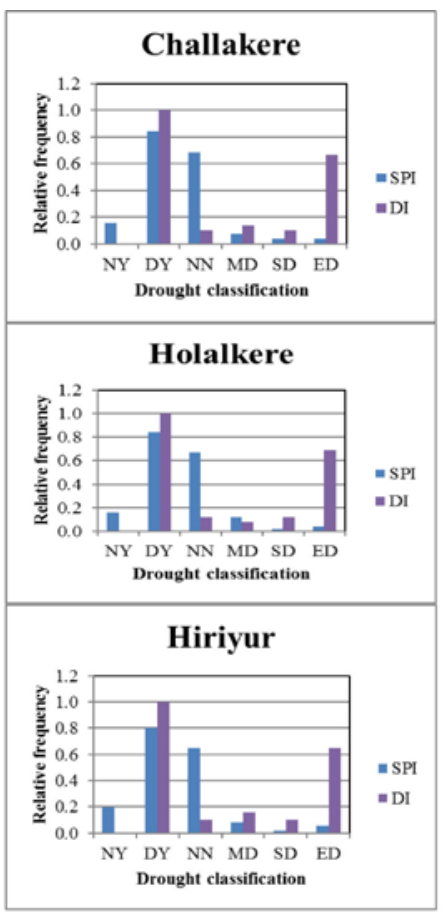

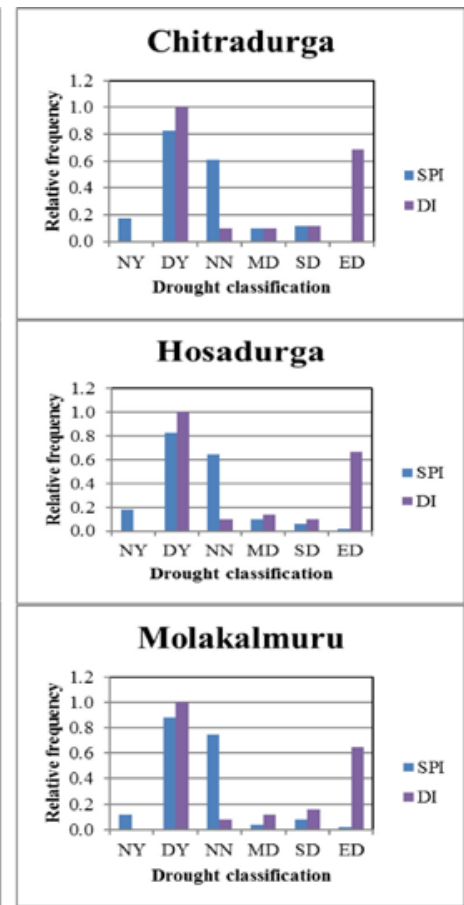

Fig. 2: Histograms of the drought frequency classes of SPI with PN and DI for six talukas of the Chitradurga district from 1967 to 2017. Where, (ED - Extremely Dry; SD - Severely Dry; MD - Moderately Dry; NN - Near Normal; DY - Drought Years; NY - Normal Years)

with SPI assessed for the period 1967 to 2017 revealed that the two indices showed good relationship with each other having linear regression during normal and wet months. The $\mathrm{R}^{2}$ values for all the six taluks under study ranged from 0.97 to 0.99 for CZI and SPI. Similarly, ZSI also showed strong correlation with SPI however, the Z-score index value tends to be less during dry periods and high during very wet periods as compared to SPI values. The $\mathrm{R}^{2}$ ranged from 0.95 to 0.98 for SPI and ZSI comparison (Fig. 1). Similar kind of comparison between CZI and ZSI with SPI for drought monitoring in Iran and Central India respectively was reported by Morid et al. (2006) and Jain et al. (2015).

\section{Comparing PN with SPI}

The PN drought index was compared with SPI by combining all the wet classes of SPI into single class. The results after comparing two indices have revealed that, only the 'normal class' of SPI exhibited higher values than that of PN for all the six taluks studied. Conversely, the remaining classes of PN recorded larger values than SPI revealing PN's sensitivity for change in precipitation (Fig. 2). Similar kind of study was made by Shahabfar and Eitzinger (2013); Salehnia et al. (2017) who estimated and compared drought indices using precipitation data of meteorological station and grided data of Iran.

\section{Comparing DI with SPI}

DI was also compared with SPI to characterize drought in six different talukas of Chitradurga. The relative frequencies of dry and wet classes computed by DI and SPI reveals that normal class in DI differed from that of SPI as observed in PN (Fig. 2). The magnitude ranges from 0.1 to 0.2 for normal class in SPI for Molkalmuru and Challakere taluks respectively. Whereas, no normal status was declared by DI. But with other drought indices, DI exhibited higher 'extreme drought' events than that of normal class. These findings are in conformity with Dogan et al. (2012) and Dikici (2020) who assessed DI in comparison with SPI for drought characterization in their study.

\section{CONCLUSION}

From the present drought assessment study conducted for six taluks of Chitradurga district it can be concluded that, out of five meteorological drought indices used, performance of CZI, ZSI and SPI was similar and better compared to PN and DI. PN was found very much sensitive to changes in precipitation leading to larger variations in dry events. Similarly, DI recorded more number of 'extreme 
drought' events which may lead to misinterpretation of results in drought characterization. Thus, PN and DI should not be used for analysing drought events in Chitradurga. However CZI, ZSI and SPI which were found to be the best drought indicators can be recommended for drought assessment and characterization for different time-scales in Chitradurga district of Karnataka using long-term precipitation data.

\section{ACKNOWLEDGMENT}

The authors would like to acknowledge the Director, Karnataka State Natural Disaster Monitoring Centre, Bangalore for providing the rainfall data and the financial support from the Directorate of Research, University of Agricultural and Horticultural Sciences, Shivamoga for sanctioning Staff Research Project (SRP) fellowship for this study.

\section{REFERENCES}

Barua, S., Ng, A.W.M. and Perera, B.J.C. (2011). Comparative evaluation of drought indexes: case study on the Yarra River catchment in Australia. J. Water Resour. Plan. Manag., 37: 215-226.

Bhalme, H.N. and Mooley, D.A. (1980). Large-scale droughts/floods and monsoon circulation. Mon. Weather Rev., 108: 1197-1211.

Byun, H.R. and Wilhite, D.A. (1999). Objective quantification of drought severity and duration. J. Climatol., 12: 2747-2756.

Dai, A. (2011). Characteristics and trends in various forms of the Palmer Drought Severity Index during 1900-2008. J. Geophys. Res., 116:D12115, doi: 10.1029/2010JD015541.

Deepa, B.K., Shweta, G., Himani, B., Shraddha, R. and Arnab, K. (2019). Drought assessment for Kharif rice using standardized precipitation index (SPI) and vegetation condition index (VCI). J. Agrometeorol., 21(2):182-187.

Dikici, M. (2020). Drought analysis with different indices for theAsi Basin (Turkey). Sci. Rep., 10:20739. doi. org/10.1038/s41598-020-77827-z

Dogan, S., Berktay, A. and Singh, V.P. (2012). Comparison of multi-monthly rainfall based drought severity indices with application to semi-arid Konya closed basin, Turkey. J. Hydrol., 470 (71): 255-268.

Edwards, D.C. and McKee, T.B. (1997). Characteristics of $20^{\text {th }}$ century drought in the United States at multiple timescales. Atmos. Sci. Pap., 63:1-30.

Gibbs, W.J. and Maher, J.V. (1967). Rainfall deciles as drought indicators. Bur. Meteorol., Bulletin No.48, Melbourne, Australia.

Hayes, M.J. (2006). Drought Indices. Van Nostrand's Scientific Encyclopedia. Hoboken: John Wiley \& Sons, Inc. doi:10.1002/0471743984.vse8593.

Jain, V.K., Pandey, R.P., Jain, M.K. and Byun, H.R. (2015). Comparison of drought indices for appraisal of drought characteristics in the Ken River basin. Weather Climate Extremes, 8:1-11.

Ju, X.S., Yang, X.W. and Chen, L.J. (1997). Research on determination of station indexes and division of regional flood/drought grades in China. Quarterly $J$. Appl. Meteorol., 8(1): 26-33.

Keyantash, J. and Dracup, J.A. (2002). The quantification of drought: an evaluation of drought indices. Bull. Am. Meteorol. Soc., 83:1167-1180.

McKee, T. B., Doesken, N. J. and Kleist, J. (1993). The relationship of drought frequency and duration to time scales. In: Proceedings of the $8^{\text {th }}$ Conference on Applied Climatology, Anaheim, CA, USA, p.179184.

Morid, S., Smakhtin,V. and Moghaddasi, M. (2006). Comparison of seven meteorological indices for drought monitoring in Iran. Int. J. Climatol., 26: 971-985.

Narasimhan, B. and Srinivasan, R. (2005). Development and evaluation of soil moisture deficit index (SMDI) and evapotranspiration deficit index (ETDI) for agricultural drought monitoring. Agric. For. Meteorol., 133:69-88.

Palmer, W.C. (1965). Meteorological drought. US Department of Commerce, Weather Bureau, Technical Paper 45. p. 58 . 
Palmer, W.C. (1968). Keeping track of crop moisture conditions nationwide: the new crop moisture index. 21: $156-161$.

Pandey, R.P., Dash, B.B., Mishra, S.K. and Singh, R. (2008). Study of indices for drought characterization in KBK districts in Orissa (India). Hydrol. Process., 22:1895-1907.

Pathak, A.A. and Dodamani, B.M. (2019). Comparison of Meteorological Drought Indices for Different Climatic Regions of an Indian River Basin. AsiaPacific J. Atmospheric Sci., 56(7058):1-14. doi: 10.1007/s13143-019-00162-5.

Pradhan, S., Sehgal, V., Das, D. and Singh, R. (2011). Analysis of meteorological drought at New Delhi using SPI. J. Agrometeorol., 13(1): 68-71

Salehnia, N., Alizadeh, A., Sanaeinejad, H., Bannayan, M., Zarrin, A. and Hoogenboom, G. (2017). Estimation of meteorological drought indices based on AgMERRA precipitation data and station-observed precipitation data. J. Arid Land, doi.org/10.1007/ s40333-017-0070-y.

Shafer, B.A. and Dezman, L.E. (1982). Development of a surface water supply index (SWSI) to assess the severity of drought conditions in snow pack runoff areas. Western Snow Conference, Reno, NV, Colorado State University. pp.164-175.

Shahabfar, A. and Eitzinger, J. (2013). Spatio-temporal analysis of droughts in semi-arid regions by using meteorological drought indices. Atmosphere, 4(2): 94-112.
Smakhtin, V.U. and Hughes, D.A. (2007). Automated estimation and analyses of meteorological drought characteristics from monthly rainfall data. Environ. Model. Softw., 22: 880-890.

Tsakiris, G., Pangalou, D. and Vangelis, H. (2007). Regional drought assessment based on reconnaissance drought index (RDI). Water Resour. Manag., 21(5): 821-833.

Vindhya, N.M. (2008). Drought risk assessment in Chitradurga district of Karnataka using remote sensing and GIS, Ph.D. thesis, Dept. Applied Geology, Kuvempu University, Karnataka.

Wable, S.P., Jha, M.K., Shekhar, A. (2019). Comparison of drought induces in semi-arid river basin of India. Water Resour Manage., 33, 75-102. doi:10.1007/ s11269-018-2089-z.

Willeke, G., Hosking, J.R.M. and Wallis, J.R. (1994). The national drought atlas. In: Institute for Water Resources Report 94-NDS-4. U.S Army Corp of Engineers, CD-ROM. Norfolk, VA.

WMO (World Meteorological Organization). (1975). Drought and Agriculture. Technical Note No. 138, Report of the CAgM Working Group on Assessment of Drought, WMO, Geneva, Switzerland. p.127.

Wu, H., Hayes, M.J., Weiss, A. and Hu, Q.I. (2001). An evaluation of the standardized precipitation index, the china-Z index and the statistical Z-Score. Int. $J$. Climatol., 21:745-758. 